\title{
Central Artery
}

National Cancer Institute

\section{Source}

National Cancer Institute. Central Artery. NCI Thesaurus. Code C32277.

A branch off of the terminal section of the middle cerebral artery running through the cortex on both sides of the central sulcus. 